\title{
CONSTRUCT VALIDATION OF ENTREPRENEURIAL CHARACTER SCALE
}

\author{
Aftina Nurul Husna ${ }^{1}$, Nur Akmal ${ }^{2}$ \\ ${ }^{1}$ Fakultas Psikologi \& Humaniora, Universitas Muhammadiyah Magelang, \\ Jalan Tidar No. 21 Kota Magelang, Jawa Tengah, Indonesia 56126 \\ ${ }^{2}$ Fakultas Psikologi, Universitas Negeri Makassar \\ Jalan A.P. Pettarani Kota Makassar, Sulawesi Selatan, Indonesia 90222 \\ anhusna@ummgl.ac.id
}

\begin{abstract}
This article reports on the effort to test psychometric properties of the revised version of Skala Karakter Wirausaha (SK-Wira). The research aims to clarify the scale's internal structure by examining its construct validity. Construct validity is proven through confirming the internal structure and associating the scale with relevant variables. Revised version of SK-Wira and other measures were administered to university students in Magelang and Makassar $(N=598)$. After completing CFA, Study 1 confirmed that SK-Wira can be used as both multidimensional scale (model 1) to measure general entrepreneurial character, and unidimensional scales (model 2) to measure specific domains separately. Both models showed good fit. In Study 2, general and specific domains of entrepreneurial character were correlated with hope of success, fear of failure, openness to experience, neuroticism, entrepreneurial intention, and entrepreneurial self-efficacy. The results accepted all proposed hypotheses. In conclusion, SK-Wira is a valid instrument to measure entrepreneurial character for psychology of entrepreneurship research.
\end{abstract}

Keywords: entrepreneurial characteristics; entrepreneurial characters scale; construct validation

\begin{abstract}
Abstrak
Artikel ini melaporkan upaya menguji properti psikometrik Skala Karakter Wirausaha (SK-Wira) versi revisi. Penelitian ini berusaha mengklarifikasi struktur internal skala dengan memeriksa kembali validitas konstruknya. Validitas konstruk dibuktikan dengan mengkonfirmasi struktur internal dan mengasosiasikan skala dengan variabel lain yang relevan. SK-Wira yang direvisi dan sejumlah instrumen lainnya diberikan kepada mahasiswa di Magelang dan Makassar $(N=598)$. Setelah melakukan EFA dan CFA, Studi 1 mengkonfirmasi bahwa SKWira dapat digunakan baik sebagai skala multidimensional (model 1) untuk mengukur karakter wirausaha secara umum maupun skala unidimensional (model 2) untuk mengukur domain-domainnya yang spesifik secara terpisah. Kedua model menunjukkan good fit. Pada Studi 2, karakter wirausaha secara umum dan domain spesifiknya dikorelasikan dengan hope of success, fear of failure, openness to experience, neuroticism, intensi wirausaha, dan efikasi diri wirausaha. Hasilnya, semua hipotesis yang diajukan diterima. Disimpulkan, SK-Wira adalah instrumen yang valid untuk mengukur karakter wirausaha bagi penelitian psikologi kewirausahaan.
\end{abstract}

Kata kunci: karakteristik wirausaha; skala karakter wirausaha; validasi konstruk

\section{INTRODUCTION}

Entrepreneurial character is among the earliest topic studied in the field of psychology of entrepreneuship. As an approach to understand entrepreneur as individual, research on personality traits seek to answer questions that are frequently asked: Why do some people become entrepreneurs while others do not? Why do some people become successful entrepreneurs while others fail? (Hisrich, Langan-Fox, \& Grant,
2007; Rauch \& Frese, 2000) In the past, this approach was abandoned because it tended to simplify the entrepreneurial phenomenon as personality issue. Compared to studies on contextual/ situational factors or environmental factors, it lacked satisfying answer to questions regarding entrepreneurial behavior dan process (Rauch \& Frese, 2014).

The personality approach is on the rise again along with the development of industrial and organizational psychology. Many researches 
gain more evidence that personality factors determine various organizational and leadership behaviors in organizations (Rauch $\&$ Frese, 2014). This finding is relevant for the study of entrepreneurship because entrepreneurship itself is basically the formation of a new business organization. Entrepreneurs are founder, owner, and manager of business organizations. Their decision to start a business is influenced by their personality (Rauch \& Frese, 2000).

Entrepreneurial character is one of main factor that affect entrepreneurial activity. It determines whether a person will tend to self-employ and whether he/ she will be successful in business (Kusmintarti, Thoyib, Maskie, \& Ashar, 2016; Salamzadeh, Farjadian, Amirabadi, \& Modarresi, 2014). In the Giessen-Amsterdam Model of of small business owners success (in Rauch \& Frese, 2000), personality is an important human capital. Personality affects the success of an entrepreneur indirectly through goal setting and strategic choices in running a business (Rauch \& Frese, 2000). A meta-analysis conducted by Frese and Gielnik (2017) also found that the personality characteristics of entrepreneurs positively correlated with the establishment of new businesses and business performance.

Entrepreneurial character is a complex personality concept that cannot be limited to only one psychological construct. McClelland was the pioneer to examine entrepreneurial character by introducing the concept of achievement motivation in/ nAch in 1960s (Hisrich et al., 2007). In the next decades, more new constructs were generated to describe the personality of an entrepreneur. Frese and Gielnik (2017) has identified many personal qualities in addition to achievement motivation e.g., self-efficacy, proactive personality, risk propensity, innovativeness, stress tolerance, autonomy, and internal locus of control. General personality theory such as Big Five Personality also is taken into consideration to explain the differences between entrepreneurs and managers (Frese \& Gielnik, 2017).

Current theory of entrepreneurial personality classifies entrepreneurial traits into two major groups, i.e., distal traits and proximal traits. This classification is based on differences in the predictive power of various traits (Rauch \& Frese, 2014). Distal traits are general personality traits, such as the Big Five Personality. Proximal traits are more specific characteristics that lead to specific processes. Proximal traits such as selfmotivation and self-efficacy are closer to behavior and therefore, are stronger predictors of performance than distal traits (Rauch \& Frese, 2014). According to Baum and Locke (in Rauch and Frese, 2014), proximal traits is more determining for entrepreneurial competence rather than the distal traits.

Based on the conceptualization above, entrepreneurial characters are defined as proximal traits which determine entrepreneur's choice to start and engage in business and his/ her performance in conducting business. According to Rauch and Frese (2014), these characteristics include need for achievement, risk taking, innovativeness, autonomy, internal locus of control, and self-efficacy. Entrepreneurial characteristics are related but distinguished from entrepreneurial competence. Entreprenerial competence is among overt and trainable behaviors or skills that show the quality of actions an entrepreneur takes in running his business. Entrepreneurial characteristics are intrapsychic. It may change, but takes a long time and sometimes requires the help of psychological interventions, such as therapy, counseling, or entrepreneurial education (Bird, 2019).

Need for achievement is the main source of motivation for a person to choose independent business as a career choice. It determines their performance and persistence in doing business (Carraher, Buchanan, \& Puia, 2010; Collins, Hanges, \& Locke, 2004; 
Wu, Matthews, \& Dagher, 2007). Achievement motivation defined as a moderate preference for challenging tasks rather than those that are routine or very difficult. Individuals with achievement motivation desire to be responsible for their performance, to seek feedback, and better ways to improve performance. This trait is positive and significantly related to business success so it is considered as the most important characteristic of successful entrepreneurs (Rauch \& Frese, 2014). The existence of achievement motivation explains the entrepreneur's successful process because it determines the amount of commitment and persistence a person has (McClelland, dalam Stewart \& Roth, 2001).

It can be said that risk-taking is one of the consequences of the need for achievement (Stewart \& Roth, 2001). Taking risk is individual's disposition toward risk. In a business context, an entrepreneur is called a risk taker because he tends to choose to realize business ideas even though the probability of success is low (Rauch \& Frese, 2014). In one theory, risk taking has a direct linear correlation with business creation and success because entrepreneurship requires decision making in the face of uncertainty. As a result, individuals who are more tolerant of risk are more likely to start a business than those who avoid risk (Antonites \& Wordsworth, 2009). However, another theory explains the effect of risk-taking showing curvilinear correlation. For business success, entrepreneurs also tend to choose moderate risks in order to protect their business especially if they are business owners (Rauch \& Frese, 2014).

Innovativeness is willingness and interest to seek novelty regarding ways of acting. In a business context, this is the tendency for someone to introduce new products and services, to open new markets, and to introduce new production processes, technology, and research findings in order to develop his company (Rauch \& Frese, 2014). Innovativeness can occur at a personal level as well as at a company level. Innovation directly contributes to the creation of new business and its success. Innovation at the personal level can be seen from the enjoyment of individuals looking for and trying new things so that tasks can be completed more effectively and efficiently (Utsch \& Rauch, 2002).

Autonomy describes a person's tendency to work independently or to be independent from the influence of others in regulating what he does. Desire to be independent is often the reason why someone decides to become an entrepreneur. Unlike employees who depend on the instructions and supervision of superiors, an entrepreneur must be able to make decisions without the supervision of others, set goals and build plans independently, and control their own execution. To become an entrepreneur, one needs autonomy to work without restrictions and rules set by the organization (Lumpkin, Cogliser, \& Schneider, 2009; Rauch \& Frese, 2014). This autonomy is related to internal locus of control. Individual with internal locus of control believe that he is the main actor of his life. However, the findings regarding the role of autonomy in business success are less convincing because the resulting correlation tends to be weak although significant (Rauch \& Frese, 2014). This is understandable because business is always run in the context of collaborating with others. A businessman cannot be a solo player.

Having self-efficacy also characterizes an entrepreneur. In general, people with high self-efficacy will be more resilient when problems arise and find solutions to solve them. They have more personal initiative, are more optimistic for success, and think further to the future, so they perform better (Krueger, Jr. \& Brazeal, 1994; Rauch \& Frese, 2014). Entrepreneurial self-efficacy is conceptualized as one's belief that he can play his role and carry out tasks in entrepreneurial activities (Newman, Obschonka, \& Schwarz, 2018).. 
Entrepreneurial self-efficacy is known as predictor of intention to be entrepreneurial (Zhao, Seibert, \& Hills, 2005).

Based on the conceptualization of entrepreneurial characteristics above, Husna, Zahra, and Haq, (2018) defined the character of entrepreneurship consisting of achievement motivation, innovativeness, autonomy, and risk taking. The internal locus of control is not included because it is closely related to autonomy. Both of these concepts are rooted in the concept of agency in social cognitive theory (Bandura, 2018). Meanwhile, regarding entrepreneurial selfefficacy, even though it is classified as a personality factor, it is a cognitive variable that determines the level of motivation and work performance (Stajkovic \& Luthans, 1998). The conceptualization of entrepreneurial self-efficacy itself refers to entrepreneurial competencies that are close to aspects of behavior in business activities (McGee, Peterson, Mueller, \& Sequeira, 2009). Entrepreneurial self-efficacy can be improved through business experience, entrepreneurship education and training, and process modeling (Brändle, Berger, Golla, \& Kuckertz, 2018; Laviolette, Lefebvre, \& Brunel, 2012; Zhao et al., 2005). This is quite contradictory to the concept of personal character which takes time and effort to change. Consequently, self-efficacy is classified as part of entrepreneurial characteristics.

A person is said to have entrepreneurial characters if he shows high achievement motivation, is innovative, tends to take risks rather than avoid them, and is independent in decision making (Husna et al., 2018). To measure entrepreneurial characters, Husna et al. (2018) developed the Entrepreneurial Characters Scale (SK-Wira). The scale is designed to be multidimensional with interrelated aspects and consists of 22 favorable items. This scale is written in Likert format with a 5-point response ranging from 1 (very disagree) to 5 (very agree). Internal consistency checking showed that the scale has excellent reliability. This scale is also valid in construct. SK-Wira met the criteria for absolute fit indices $\left(\chi^{2} / d f=1.19\right.$ : 1 ; RMSEA $=.038$; SRMR $=.069)$, although it did not meet the criteria of incremental fit indices $>.95(\mathrm{CFI}=.943 ; \mathrm{TLI}=.936)$.

The scale is considered to have several weaknesses that prevent it for future studies in a wider context. The sample size is not large enough, only 130 people, which is not ideal for CFA (at least > 200 people). The sample is a group of university student, thus limiting the use of the scale in other sample groups. There are also indications that the data is positively skewed, which may explain why the CFA results were less than satisfactory. In addition, there are aspects that are lacking in items, so it is advisable to increase the number of items (Husna et al., 2018).

Based on the problems above, this research is conducted to follow up the development of SK-Wira to improve the psychometric quality of this scale. This study aims to reexamine the construct validity of SK-Wira by conducting CFA on a revised scale with the addition of items. After that, we correlate entrepreneurial character constructs with other related psychological constructs.

Construct validity is the heart of the validity of psychological measurement. The validity of a construct can be proven using five approaches: The content of the scale (content validity), internal structure (dimensionality), the psychological processes used to respond to the scale, the consequences of using it, and the association between the scale score and other variables (Furr, 2011). Associating one variable with other psychological variables is the most frequently used approach for validity checking. This approach places the scale in the context of other variables. It is useful in providing insight into the constructs that affect the scale score. If the scale is developed in accordance to a certain theoretical basis, then the scale will form a kind of network to any variables with which 
the result of the measurement would be either similar and correlated, or dissimilar and uncorrelated (Furr, 2011).

There are four types of associations that can be investigated as evidence of construct validity. Two of them were carried out in this study. First, convergent validity, which is the degree to which scale scores are associated with the measurement results of psychological constructs that are theoretically known to be related due to similarities in theoretical foundations (Furr, 2011). Second, concurrent validity, which is a type of evidence collected to maintain the use of a scale; that the scale is able to predict the results of other variables that become criteria (Drost, 2011; Furr, 2011). Concurrent validity is very useful because it can be evidence that a scale can be used as a substitute for a similar scale, even if the scale has less satisfactory reliability (Cronbach in Bergkvist \& Rossiter, 2007, pp. 176).

To examine convergent validity, entrepreneurial characters as measured by SK-Wira is correlated to four variables: hope for success and fear of failure, both of which are uncorrelated dimensions of achievement motive (Lang \& Fries, 2006) and openness to experience and neuroticism which are two of the five dimensions in the Big Five personality theory (McCrae \& Costa, 2013; Ramdhani, 2012). Each of these variables is conceptually related to the dimensions in SKWira, i.e., achievement motivation, innovativeness, and risk taking. The dimension of achievement motivation is built based on McClelland's motivation theory (in Stewart \& Roth, 2007). Achievement motivation is defined as the desire to do the best, to achieve satisfaction, and a sense of accomplishment from challenging tasks. Meanwhile, the innovativeness dimension is considered as an expression of one's tendency to be open to new experiences, while the risk-taking dimension is a manifestation of a low tendency to become anxious. Each of them relates to aspects of openness to experience and neuroticism in the Big Five personality theory (McCrae \& Costa, 2013).

The examination of concurrent validity is carried out by correlating entrepreneurial characters to two entrepreneurial variables. These variables were predicted based on previous research to be correlated with achievement motivation, innovativeness, autonomy, and taking risks (Brandstätter, 2011; Rauch \& Frese, 2000). These variables are first individual entrepreneurial, intention the intention and plan to start a business which is a precursor to real entrepreneurial behavior (Liñán \& Chen, 2009; Thompson, 2009). The second is entrepreneurial selfefficacy, a person's belief to his ability that he is able to launch and develop a business (McGee et al., 2009).

This research consisted of two studies. The first study aims to validate the construct of entrepreneurial characters. We re-check the dimensionality by conducting Confirmatory Factor Analysis to determine the internal structure of SK-Wira. The issues to be confirmed through the first study are: Is SKWira a multidimensional or unidimensional scale? How is the internal structure of the two models? The second study also aims to validate the construct by correlating entrepreneurial characters to other relevant variables.

$\mathrm{H}$ 1: There is a positive relationship between entrepreneurial characters and achievement motives.

$\mathrm{H}$ 2: There is a positive relationship between entrepreneurial character and openess to experience.

$\mathrm{H}$ 3: There is a negative relationship between entrepreneurial character and neuroticism.

$\mathrm{H}$ 4: There is a positive relationship between entrepreneurial character and entrepreneurial intention.

$\mathrm{H}$ 5: There is a positive relationship between entrepreneurial character and entrepreneurial self-efficacy. 


\section{METHODS}

\section{Participants and Research Locations}

The research was conducted in April-July 2019 in two different cities, Magelang and Makassar for heterogeneous resources reason. First, researchers conducted trials before the actual research. The number of participants in the trial was 81 students (40 in Magelang and 41 in Makassar). In order to meet the standards of construct validity testing, researchers need more than 200 participants. In this study, there were 598 participants from the faculties of law, health sciences, engineering, Islam, pedagogy, economics and business, psychology and humanities.

Table 1.

Participants Characteristics

\begin{tabular}{ll}
\hline nnn & $\mathrm{mmm}$ \\
\hline Locations & \\
Magelang & 298 \\
Makassar & 300 \\
\hline Gender & \\
Male & $66.7 \%$ \\
Femal & $33.3 \%$ \\
N/A & $.3 \%$ \\
\hline Age & \\
Range & $17-25$ \\
Mean & 19.38 \\
SD & 2.03 \\
\hline Business experience & \\
Yes & $38.8 \%$ \\
No & $56 \%$ \\
N/A & $5.2 \%$ \\
\hline
\end{tabular}

The sample was obtained by using convenient sampling with proportions. Researchers decided for this technique because the hypothesis is not a research hypothesis, but a measurement hypothesis. Besides, this technique is suitable, practical and efficient based on the condition of the researcher. Of the total 598 collected questionnaires, 551 questionnaires met the research criteria. A total of 47 questionnaires could not be used because of missing data. Although not all participants answered questions about age and entrepreneurial experience, an overview of the proportion of participants based on their characteristics is apparent in Table 1.

\section{Research Instruments}

The initial version of SK-Wira contained 22 items. Cronbach's a coefficient $=.863$, indicating good reliability of the scale. However, the item's distribution on this scale was not proportional, so new items it was necessary to add. Researchers added two items to the risk-taking aspect, e.g. "I dare to take risky actions to achieve the target," and "I am interested in trying alternative ways, although the results are not yet certain." The SK-Wira consists of 24 items.

To test convergent validity, researchers correlated entrepreneurial character with the first, achievement motivation. Ten items of Achievement Motivation Scale (AMS) (Lang $\&$ Fries, 2006) measured the achievement motivation. The researchers translated and adapted the scale into Indonesian. This scale uses a four-point Likert format $(1=$ very unsuitable, $4=$ very suitable), and consists of two aspects, the hope of success ("I enjoy situations where I can use my abilities") and fear of failure ("I feel uneasy about doing something if I'm not sure it will work"). Second, researchers use adapted version the Big Five Personality in bahasa Indonesia by Ramdhani (2012) on the aspects of openness to experience and neuroticism. It consists of six and four items in a 5-point Likert format ( $1=$ very unsuitable, $5=$ very suitable $)$.

Meanwhile, to test the concurrent validity, researchers correlated the character of entrepreneurship with the entrepreneurial intention and the entrepreneurial selfefficacy. Researchers used ten adapted items of Individual Entrepreneurial Intention Scale/ IEIS to measures entrepreneurial intention (Thompson, 2009). This scale uses 6-point Likert format $(1=$ very untrue, $6=$ very true). Participants were instructed to think about themselves, how true or false it is that you they perform actions indicating intentions for entrepreneurship such as 
"Saving money to start a business" and "Spending time learning how to start a business". Entrepreneurial self-efficacy was measured using Entrepreneurial SelfEfficacy Scale / ESES (McGee et al., 2009).. It consists of 19 items with a 5-point Likert format. The researchers have adapted both of scales and published it in Husna dan Akmal (2020).

The adaptation process consists of translating a scale from English into Indonesian by following the procedures of Gudmundsson (2012). Previously, researchers chose the instrument and a qualified translator, select a qualified expert to examine the instrument, choose the right translation and adaptation method, conduct a pilot-study and field studies, and finally perform psychometric property examinations. Researchers used back-translation as method of translation and adaptation (Sousa \& Rojjanasrirat, 2011).

\section{Instrument Trial}

The trial aimed to check the reliability of all scales used in this study. The results are as follows:

SK-Wira. Revised SK-Wira has the Cronbach Alpha coefficient $\alpha=.875$, which means that the reliability is good. Even so, item number 19 from the achievement motivation aspect "I want to learn more" has $r_{\mathrm{i}-\mathrm{x}}<.3$. The item is dropped from the scale so that SK-Wira consist of 23 items with details: achievement motivation aspect consisting of five items, risk-taking six items, innovativeness seven items, and autonomy five items. The achievement motivation, innovativeness, autonomy, and risk-taking subscales showed respectively the coefficient $\alpha$ of $.655, .735$, .620 , and .614 .

Achievement Motivation Scale (AMS). The AMS is a multidimensional scale with two dimensions, hope of success and fear of failure. Because the two dimensions are uncorrelated, researchers measure the reliability per aspect. From the two dimensions, the reliabilities are $\alpha=.714$ (acceptable) and .869 (good), thus no item is dropped.

Big Five Personality. Researchers measured only two dimensions of Big Five, openness to experience and neuroticism. Due to the uncorrelated nature of multidimensional scales, researchers measure the reliability per aspect, $\alpha=.778$ (accepted) for the dimension of openness to experience and .896 (good) for the dimension of experience and neuroticism, and no item is dropped.

Individual Entrepreneurial Intention Scale (IEIS). Of the ten items, four items were distractors, so they were not analyzed. The first reliability test is $\alpha=.597$. After going through the selection process, it remained only four good items (numbers 1, 6, 9 and 10) with $\alpha=.616$ and forms a dimension. This weak reliability is due to the small number of items. The small number of items is one of the factors affecting the quality of reliability. However, this scale was still used because after more detailed observation of dimensionality and correlation between items, all items showed good indicators.

Entrepreneurial Self-Efficacy Scale (ESES). ESES have $\alpha$ of .938 (very good), and all items passed the selection.

\section{Data Analysis}

To test the hypothesis in Study 1, the researchers examined the dimensionality of SK-Wira by carrying out an Exploratory Factor Analysis (EFA) and continued with an internal consistency check to determine the reliability. The researchers used the SPSS 20 program. After knowing the dimensions, the researchers confirmed the internal structure by running a Confirmatory Factor Analysis (CFA), using the MPlus 7 program. In Study 2 , the researchers tested the relationship hypothesis with the Pearson correlation. Previously, at the data preparation stage, the researcher conducted a normality and linearity test and obtained normal and linear curves, even though there were several outliers. Researchers use the SPSS 20 program to assumptions testing. 


\section{RESULTS AND DISCUSSION}

\section{Study 1}

Dimensionality. The addition of two new items for the risk-taking aspect and the reduction of one item in the achievement motivation aspect led to a consideration that the SK-Wira (23 items) needs to be re-tested in dimensionality, reliability and internal structure. Besides, the results of previous research show ambiguous findings on whether the scale is unidimensional or multidimensional. In the previous study, items spread in four dimensions (Husna et al., 2018). In this study, those items group into and form one dimension, wherein the majority of items converged into one.

This problem becomes the reason for reexploring the entrepreneurial character construct and, most likely, modifying the scale. This development is challenging because although theoretically the four personality traits are conceptualized as entrepreneurial characters, it cannot be proved psychometrically because of insufficient evidence. The clue for unidimensionality raises a concern to analyze the SK-Wira one by one according to the subscales that compose it, i.e., achievement motivation, innovativeness, autonomy, and the risk-taking. We run the Exploratory Factor Analysis (EFA) procedure with Principal Axis Factoring (PAF) extraction method based on Eigenvalue $>1$ and Promax rotation method.

The first result, the scale of achievement motivation is only extracted by one factor so that it is a unidimensional scale $(\mathrm{KMO}=$ .748; Barlett's Test of Sphericity $=319.492$ with $p<.01)$. The five items of this scale are each other correlated significantly.

Second, the scale of innovativeness extracts two correlated factors $(r=.528)$. This EFA shows multidimensionality with correlated dimensions $(\mathrm{KMO}=.765$; Barlett's Test of Sphericity $=695.056$ with $p<.01)$. The seven items of this scale are each other correlated. Table 3 shows the structure pattern of the innovativeness scale. It appears that the second factor consists of two items. The researchers maintain these two factors because they have good factor loadings (> .30) (see Table 2). The first factor contains readiness to innovate items, while the second factor contains items related to positive attitudes (enjoyment) towards innovation.

Table 2.

Factor Loadings of Innovativeness Scale

\begin{tabular}{ccc}
\hline Items & 1 & 2 \\
\hline inv01 & .342 & $\mathbf{. 6 1 6}$ \\
inv02 & .428 & $\mathbf{. 8 7 4}$ \\
inv03 & $\mathbf{. 5 4 4}$ & .327 \\
inv04 & $\mathbf{. 6 1 3}$ & .323 \\
inv05 & $\mathbf{. 5 4 4}$ & \\
inv06 & $\mathbf{. 4 9 8}$ & .425 \\
inv07 & $\mathbf{. 5 6 2}$ & .346 \\
\hline
\end{tabular}

Third, the autonomy scale is only extracted by one factor so that it is a unidimensional scale $(\mathrm{KMO}=.693$; Barlett's Test of Spherity $=319.492$ with $p<.01)$. The five items of this scale are each other significantly correlated.

Fourth, risk taking scale is extracted by two correlating factors $(r=.410)$. This EFA result shows multidimensionality $(\mathrm{KMO}=$ .657 ; Barlett's Test of Spherity $=382.283$ with $p<.01)$. The six items of this scale are each other significantly correlated. Table 4 shows the structure pattern of the risk-taking scale. The first factor consisted of only two items, and we maintain them because of the good factor loadings (> .30) (see Table 3). The first factor contains items concerning courage to take risky actions, while the second factor contains items related to being careful in facing risks.

Table 3.

Factor Loadings of Risk-Taking Scale

\begin{tabular}{ccc}
\hline Items & 1 & 2 \\
\hline $\mathrm{rt01}$ & & $\mathbf{. 4 8 4}$ \\
$\mathrm{rt02}$ & & $\mathbf{. 5 2 7}$ \\
$\mathrm{rt03}$ & .407 & $\mathbf{. 5 3 6}$ \\
$\mathrm{rt04}$ & .303 & $\mathbf{. 5 0 8}$ \\
$\mathrm{rt05}$ & $\mathbf{. 7 0 6}$ & \\
$\mathrm{rt06}$ & $\mathbf{. 6 0 7}$ & \\
\hline
\end{tabular}


Reliability. The results of the dimensionality testing showed that SK-Wira may consist of four independent scales. Therefore, the researchers will analyze the reliability separately, one by one. There is a consequence that the four scales scores cannot be combined to produce a total score of entrepreneurial character. Table 4 shows the results of the reliability analysis for each scale.

It appears that $\alpha$ coefficient ranges from .614 to .735 , so it can be interpreted that the four scales have moderate internal consistency and can still be used. The small number of items per scale caused moderate value of $\alpha$ (Furr, 2011). Other consideration is that there are two items with item-total correlation $\left(r_{\text {i-x }}\right)$ less than .30, the fifth item on the autonomy scale and the first item on the risk-taking scale. We decided to keep the two items because when they were eliminated, $\alpha$ coefficient will be less than .60. A much better value $\alpha$ (.856) coefficient was generated from the analysis of overall SKWira's internal consistency. This scale consists of 19 items: five items of achievement motivation, five items of innovativeness, five items of autonomy, and four items of risk-taking.

Table 4.

Reliability of Entrepreneurial Character Scale (in original Bahasa Indonesia)

\begin{tabular}{lcc}
\hline Items & $r_{i-x}$ & $\alpha$ \\
\hline Achievement Motivation Scale & .333 \\
Saya mencari cara agar tugas dapat selesai dengan hasil yang sempurna. & .387 & .655 \\
Saya biasa berpikir keras untuk memecahkan masalah. & .436 & \\
Saya pribadi meningkatkan standar untuk hasil kerja saya. & .433 \\
Saya berinisiatif mencari solusi lain ketika solusi yang ada tidak memuaskan. & .450 \\
Saya terus belajar untuk mengantisipasi persoalan-persoalan baru. & \\
\hline Innovativeness Scale & .398 \\
Faktor 1 & .477 \\
Saya senang jika masyarakat berinovasi. & \\
Saya bersyukur zaman modern penuh dengan inovasi. & .449 \\
Faktor 2 & .475 \\
Saya belajar agar dapat menyesuaikan diri dengan perkembangan masyarakat. & .735 \\
Saya senang mengikuti berita-berita perkembangan inovasi. & .392 \\
Saya berusaha agar dapat ikut memanfaatkan teknik-teknik baru. & .462 \\
Saya yakin teknik-teknik baru dikembangkan untuk memudahkan hidup manusia. & .470 \\
Saya mengumpulkan modal agar dapat menggunakan teknologi baru di masa & .470 \\
depan. & \\
\hline Autonomy Scale & .321 \\
Saya membentuk diri saya sendiri untuk menjadi pribadi seperti apa di masa & \\
depan. & \\
Saya tahu yang terbaik bagi masa depan saya tanpa tergantung pada arahan orang & .470 \\
lain. & \\
Saya menentukan sendiri tujuan dan arah hidup saya. & .639 \\
Saya dapat bekerja dengan baik tanpa perlu diawasi orang lain. & .374 \\
Saya berani berpendapat untuk mempertahankan pilihan pribadi. & .289 \\
\hline
\end{tabular}


Table 4.

(continued)

\section{Risk Taking Scale}

Faktor 1

Sebelum paham untung-ruginya, saya menahan diri dari membuat keputusan.

Saya mendengarkan pendapat yang pro dan kontra dalam membuat pilihan.

Saya mengantisipasi risiko kegagalan dengan membangun strategi alternatif.

Saya mempertimbangkan faktor penyebab kegagalan dalam membangun rencana.

Saya berani melakukan tindakan yang berisiko demi mencapai target.

Saya tertarik mencoba cara-cara alternatif meski belum bisa dipastikan $\quad 358$ hasilnya.

Entrepreneurial Character Scale (total 19 items)

Internal Structure. We performed CFA procedure to check the revised SK-Wira internal structure, whether it supports multidimensionality (model 1) or unidimensionality (model 2). In model 1 , the researchers analyzed SK-Wira (19 items) following the original construction consisting of four subscales. The second-order CFA proved this model.

In model 2, we broke down SK-Wira into four independent scales: scale of achievement motivation, innovativeness, autonomy, and risktaking. The dimensionality analysis showed that the scale of achievement motivation and the scale of autonomy consist of only one dimension so that CFA is carried out to prove the unidimensional model. Meanwhile, on innovativeness and risk-taking scales which consist of more than one dimension, we also confirmed the unidimensional model. In the unidimensional model of both scales, one factor has a greater number of items. The unidimensional model of the innovativeness scale consists of 5 items, and the risk-taking scale consists of 4 items.

Table 5 presents the analysis result, and Figures 1 to 6 demonstrate the internal structure. The results written in bold in the table show that the estimates meet the model fit criteria very well, while the results in italics show the good criteria (Furr, 2011; Hooper, Coughlan, \& Mullen, 2008).
The CFA results show that the achievement motivation scale indicates good fit. This scale fulfils the criteria in all indicators so it can be concluded that its construct is valid to measure achievement motivation. Similar results can also be seen on the unidimensional version of innovative scale. Innovativeness scale shows good fit in all indicators so that it is constructively valid for measuring innovativeness. Nevertheless, the multidimensional version of innovativeness scale can also measure innovativeness. This model produces unsatisfactory results only at the index $\chi^{2} / d f$.

Differ from the two previous scales, autonomy scale and risk-taking scale, in both their alternatives 1 and 2, tend to show poor fit. Autonomy scale and 6 items version of risk-taking scale meet the excellent fit criteria only on the SMRS indicator and quite good on the CFI. Although the construct validity is unsatisfactory, autonomy scale and risk-taking scale can be used as instruments to measure autonomy and risk-taking.

Which one is better; the initial SK-Wira construction as a multidimensional scale with four subscales, or SK-Wira as a unidimensional scale? We compared the two models by re-examining the initial construction SK-Wira and the later alternative. For that purpose, we run secondorder CFA procedure. As the result, this scale fulfils the fit criteria on the $\chi^{2} / d f$, RMSEA, and SRMR indicators. The latest finding regarding the internal structure of 
SK-Wira shows that this multidimensional entrepreneurship even though it is relatively scale is valid to measure the character of poor fit in some indicators.

Table 5.

CFA Results Of SK-Wira and the Subscales

\begin{tabular}{lcccccc}
\hline Indicator & $\chi^{2} / d f$ & $p$ & RMSEA & CFI & TLI & SRMR \\
\hline Kriteria model fit & $2: 1 / 3: 1$ & $>.05$ & $<.07$ & $>93$ & $>.93$ & $<.08$ \\
SK-Wira (19 aitem) & $\mathbf{4 4 3 . 8 3 2 / 1 4 8}$ & .00 & $\mathbf{. 0 6 0}$ & .870 & .850 & $\mathbf{. 0 5 0}$ \\
Motivasi Berprestasi & $\mathbf{8 . 7 8 2 / 5}$ & $\mathbf{. 1 1 8}$ & $\mathbf{. 0 3 7}$ & $\mathbf{. 9 8 8}$ & $\mathbf{. 9 7 6}$ & $\mathbf{. 0 2 0}$ \\
Keinovatifan (5 aitem) & $\mathbf{9 . 8 7 3 / 5}$ & $\mathbf{. 0 7 8}$ & $\mathbf{. 0 4 2}$ & $\mathbf{. 9 8 7}$ & $\mathbf{. 9 7 3}$ & $\mathbf{. 0 2 1}$ \\
Keinovatifan (7 aitem) & $39.150 / 13$ & .0002 & $\mathbf{. 0 6 0}$ & $\mathbf{. 9 6 2}$ & $\mathbf{. 9 3 8}$ & $\mathbf{. 0 3 3}$ \\
Kemandirian & $26.886 / 5$ & .0001 & .089 & .925 & .851 & $\mathbf{. 0 4 1}$ \\
Pengambilan Risiko (4 aitem) & $25.196 / 2$ & .00 & .145 & .885 & .655 & $\mathbf{. 0 4 4}$ \\
Pengambilan Risiko (6 aitem) & $39.029 / 8$ & .00 & .084 & .916 & .843 & $\mathbf{. 0 4 3}$ \\
\hline
\end{tabular}

Note. $\chi^{2} / d f=$ chi-square/degree of freedom. RMSEA $=$ Root Mean Square Error of Approximation. $\mathrm{CFI}=$ Comparative Fit Index. TLI $=$ Tucker-Lewis Index. SRMR = Standardised Root Mean Square Residual.

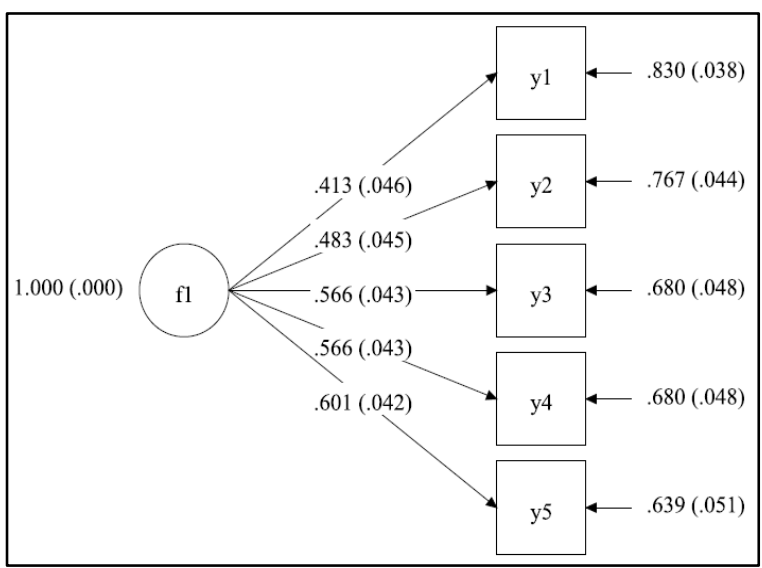

Figure 1. Internal structure of achievement motivation scale

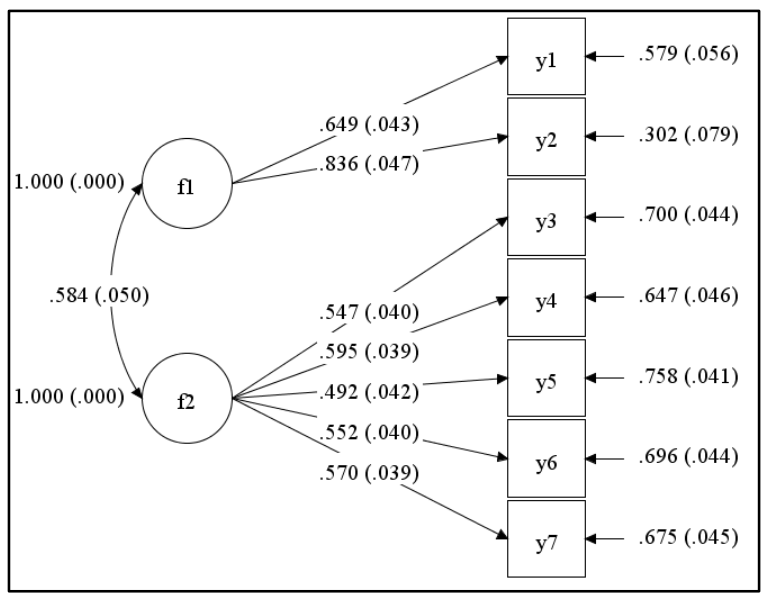

Figure 3. Internal structure of innovativeness scale ( 7 items)

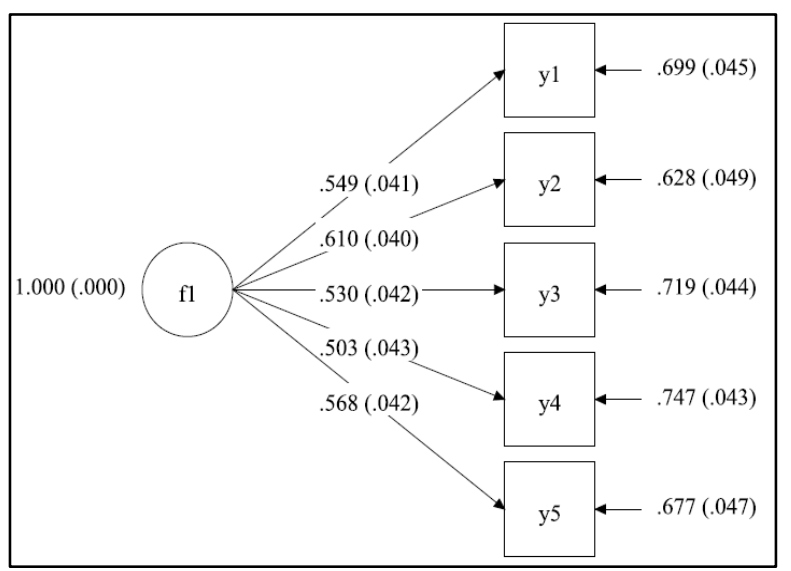

Figure 2. Internal structure of innovativeness scale (5 items)

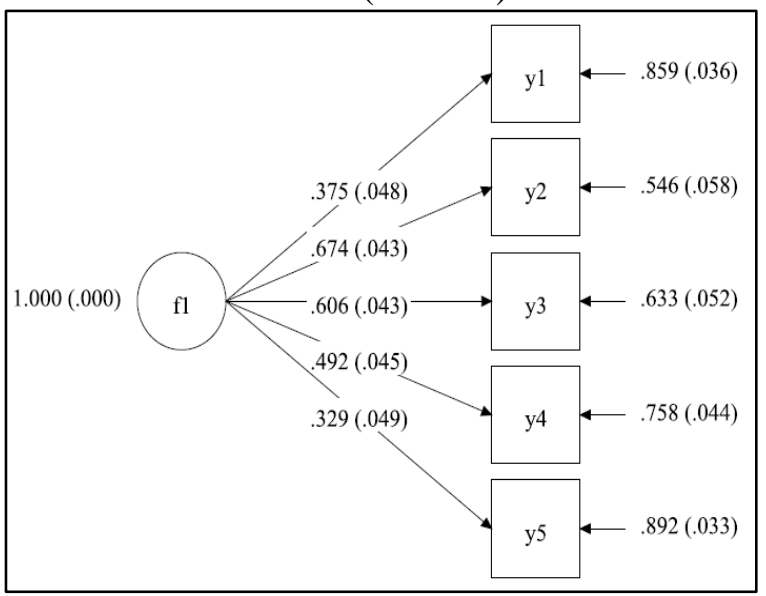

Figure 4. Internal structure of autonomy scale 


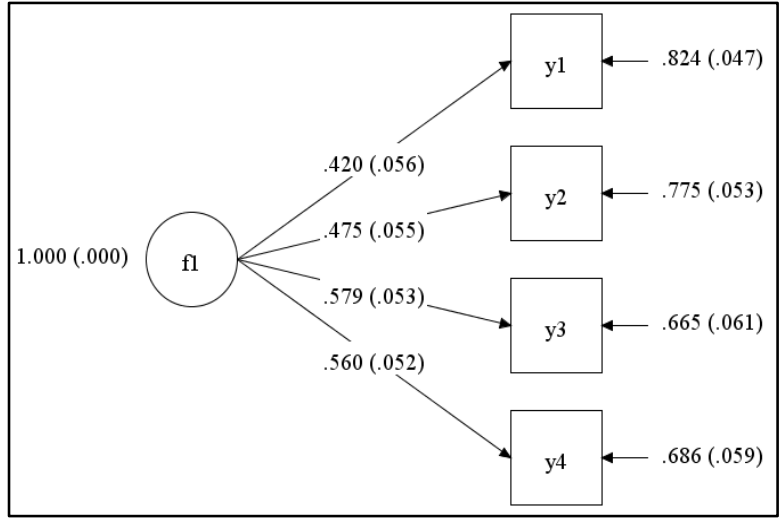

Figure 5. Internal structure of risk-taking scale (4 items)

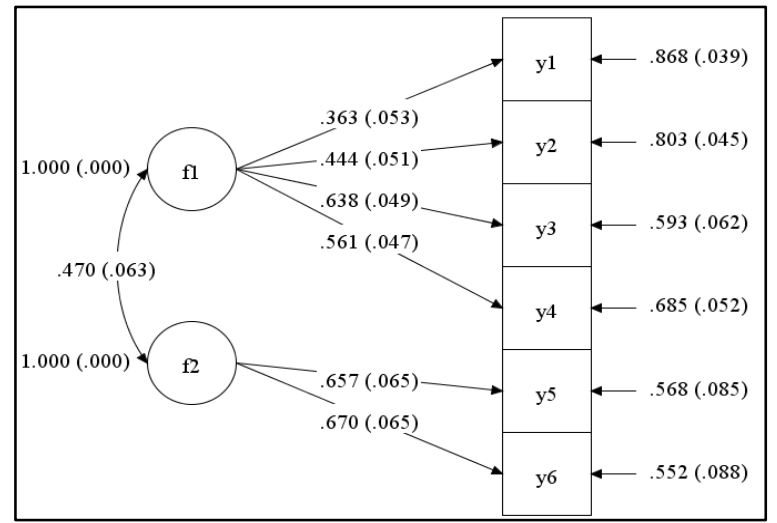

Figure 6. Internal structure of risk-taking scale (6 items)

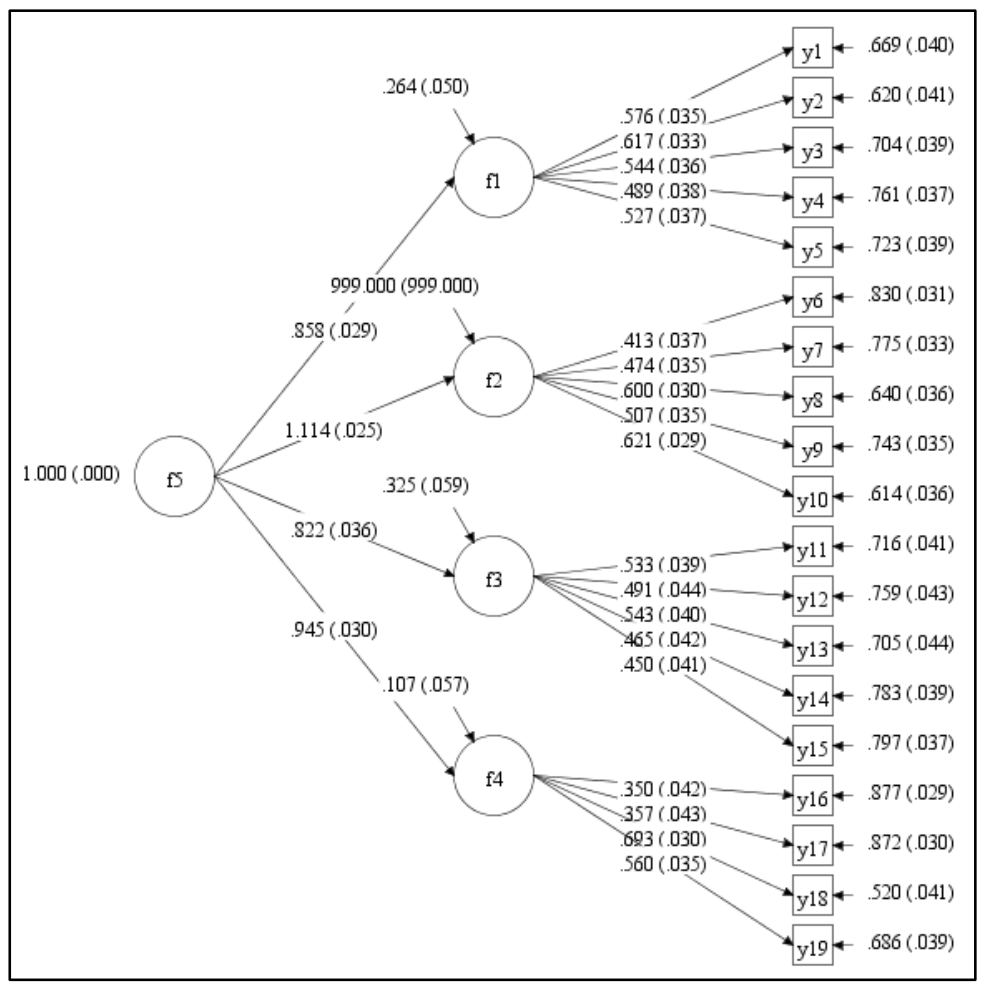

Figure 7. Internal structure of SK-Wira (19 items)

\section{Study 2}

Entrepreneurial Character Correlates. Validity examination of entrepreneurial character construct is also conducted by correlating entrepreneurial character, both in total and per aspects, with several variables. Table 6).

First, there is a positive and very significant relationship between entrepreneurial character and achievement motives in the hope of success aspect. It means that the higher the achievement motivation,
The variables are hope of success, fear of failure, openness to experience, neuroticism, individual entrepreneurial intention, and entrepreneurial self-efficacy. We used Pearson's bivariate correlation technique and the results are showed as follow (see innovativeness, autonomy, and risk-taking on a person, the higher the hope for success. However, the correlation is weak. There is no relationship between entrepreneurial character and fear of failure except in risk taking. The correlation appears weak but very significant. The tendency of risk taking 
is related to the intensity of the fear of failure.

Second, there is also a positive and very significant relationship between entrepreneurial characters and openness to experience in the Big Five personality model. A person with high achievement motivation, innovativeness, autonomy, and risk taking tends to show openness to experience. They tend to have broad insight, deep thinking (enjoy introspecting and play with ideas), original ideas, and complex experiences of mental life. Aspects of achievement motivation and risk taking have more correlations to openness to experience in comparison to the other two aspects of the entrepreneurial character. This result shows that liking to challenge and willing to take risks reflects an entrepreneur's openness to experience.

Third, there is a weak and significant negative relationship between entrepreneurial character and neuroticism, even though only in the dimensions of innovativeness and autonomy. It means that the higher a person's innovativeness and autonomy, the lower the anxiety is or in other words, the more stable his emotions are. With high innovativeness and autonomy, a person can maintain calm when confronting with stressful situations. There is a negative relationship between achievement motivation and risk-taking with neuroticism, but the relationship that is not significant.
Fourth, there is a positive and very significant relationship between entrepreneurial characters and entrepreneurial intentions. We see that the higher the achievement motivation, innovativeness, autonomy, and risk-taking, the greater the intention to be entrepreneur. The most significant correlation is in innovativeness, followed by achievement motivation. An innovative person shows a tendency to adjust to the development of innovation in society and to try new things. Meanwhile, people with achievement motivation tend to enjoy challenges and strive to achieve the best. People who like novelty and challanges tend to be more entrepreneurial than those people who are merely autonomous and dare to take risks.

Fifth, there is a positive and very significant relationship between entrepreneurial characters and entrepreneurial self-efficacy. The more intense the achievement motivation, innovativeness, autonomy, and a tendency to take high risks of a person, the more confident he is in his entrepreneurial competence. They make business plans, find resources, execute plans, and manage employees and finances. Again, the most significant character needed for an entrepreneur is innovative and achievement motivation, although independence and risktaking also appear to be equally important.

Table 6.

Correlations of Entrepreneurial Characters

\begin{tabular}{|c|c|c|c|c|c|c|}
\hline & HS & FF & $\mathrm{OE}$ & $\mathrm{N}$ & EI & ESE \\
\hline $\mathrm{EC}$ & $.279 * *$ & .017 & $.500 * *$ & $-.085 *$ & $.371 * *$ & $.460 * *$ \\
\hline $\mathrm{AM}$ & $.294 * *$ & .065 & $.439 * *$ & -.043 & $.313 * *$ & $.410 * *$ \\
\hline INV 5 aitem & $.270 * *$ & -.012 & $.403 * *$ & $-.085^{*}$ & $.379 * *$ & $.418 * *$ \\
\hline INV 7 aitem & $.299 * *$ & -.002 & $.412 * *$ & $-.088 *$ & $.400 * *$ & $.445 * *$ \\
\hline $\mathrm{O}$ & $.108 * *$ & -.049 & $.376^{* *}$ & $-.101 *$ & $.277 * *$ & $.324 * *$ \\
\hline RT 4 aitem & $.266^{* *}$ & $.157 * *$ & $.326^{* *}$ & .012 & $.189 * *$ & $.307 * *$ \\
\hline RT 6 aitem & $.258 * *$ & .059 & $.428 * *$ & -.048 & $.254 * *$ & $.364 * *$ \\
\hline
\end{tabular}

Note. $\mathrm{EC}=$ Entrepreneurial Characters. $\mathrm{AM}=$ Achivement Motivation. $\mathrm{INV}=$ Innovativeness. $\mathrm{O}=$ Autonomy. $\mathrm{RT}=$ Risk Taking. $\mathrm{HS}=$ Hope of Success. FF $=$ Fear of Failure. $\mathrm{OP}=$ Openess to Experience. $\mathrm{N}=$ Neuroticism. $\mathrm{EI}=$ Entrepreneurial Intention. ESE $=$ Entrepreneurial Self-Efficacy. ${ }^{*} p<.05 . * * p<.01$. 


\section{Discussion}

This study provides an essential insight into entrepreneurial characters construct by reinvestigating the psychometric properties of SK-Wira. The results of Study 1 indicate that there are two alternatives for using SK-Wira, and both alternatives have psychometric justification as a reliable and valid psychological measurement tool.

The first alternative is using the original construction of SK-Wira with as a multidimensional scale. This scale consists of four subscales with revised item composition (19 items). It has better internal consistency, even though the construct validity does not meet all the criteria. Because the dimensions are mutually correlated, the composite score can be calculated. This version of SK-Wira can be used if we will investigate the general character of entrepreneurship.

The second alternative is treating the subscales in SK-Wira as stand-alone scales. Achievement motivation scale is a unidimensional scale with five items. The innovativeness scale has two options, as unidimensional (five items) or multidimensional (seven items). The autonomy scale is a unidimensional scale with five items. The risk-taking scale is multidimensional with six items. Although they are lacking in reliability, these scales represent a fit model and can be used separately to measure specific domains of entrepreneurial character.

The results of Study 2 provide sufficient evidence for SK-Wira as a valid instrument with a valid construct. It can be used to predict other entrepreneurial-related variables, such as entrepreneurial intention and entrepreneurial self-efficacy. There are three findings in this study: First, characters of entrepreneurship have a positive correlation with the hope of success, entrepreneurial intention, and entrepreneurial self-efficacy. Second, the entrepreneurial characters have a negative correlation with neuroticism. Third, there is no relationship between entrepreneurial characteristics and fear of failure.

These findings support previous study as well as inspire the next research. Achievement motivation is a crucial variable that determines entrepreneurial behaviour (Carraher et al., 2010; Carsrud \& Brännback, 2011; Carsrud, Brännback, Elfving, \& Brandt, 2017; Ghasemi, Rastegar, Jahromi, \& Marvdashti, 2011). Various studies found that achievement motivation has a significant correlation with a career choice in entrepreneurship and entrepreneurial performance (Collins et al., 2004; Shane, Locke, \& Collins, 2012). What is interesting in this study is that we have the result of analysis in more detailed dimension. It appears that entrepreneurship is more driven by the hope of success rather than the fear of failure. This result explains the reason why entrepreneurial character also involves innovativeness and risk taking. One's innovativeness is influenced by his hope for success, while the willingness to take risk is possible when one is not afraid of failure.

Regarding the Big five personality traits, previous research found that entrepreneur's personality is characterized by positive values in all personality dimensions, except for neuroticism (Brandstätter, 2011). We found that innovativeness and autonomy are negatively correlated with neuroticism so that it is considered a new finding. To act in innovative way and to act independently, a person should have the courage to try something new, even the results are uncertain. Also, they have to make their own decisions. When entrepreneurs frequently face stressful situations, neuroticism can arise and hinders optimum business performance.

A very significant relationship between entrepreneurial characters and openness to experience support previous research findings. Open personality is the most crucial factor in the Big Five personality theory for entrepreneur (Antoncic, Bratkovic Kregar, 
Singh, \& Denoble, 2015; Shane, Nicolaou, Cherkas, \& Spector, 2010). Openness to experience is a factor that distinguishes entrepreneurs from non-entrepreneurs. There are creative aspects of openness that can influence the desire to act independently rather than following the norms, procedures, or culture in the organization (Antoncic et al., 2015). This study supports the development of a person-oriented model of entrepreneurship, i.e. the Entrepreneurial Personality System (EPS), which allows profiling effort toward the individual who tend to self-employ (Obschonka \& Stuetzer, 2017).

The correlation between entrepreneurial characteristics and entrepreneurial intentions supports the previous findings. Entrepreneurial intention is influenced by achievement motivation (Fini, Grimaldi, Marzocchi, \& Sobrero, 2009) and the tendency to take risks (Altinay, Madanoglu, Daniele, \& Lashley, 2012). These two aspects are aspects of entrepreneurial characters. We can predict that the stronger a person's entrepreneurial characteristics are, the greater his entrepreneurial intention is. As well as in entrepreneurial self-efficacy; the stronger a person's entrepreneurial characteristics are, the more confidence a person has in his competence. Previous research state that people with a high preference for risk have higher entrepreneurial intentions and self-efficacy in identifying opportunities (Gerhardt \& Kickul, 2007).

In this study, although there is a significant correlation between entrepreneurial characters and entrepreneurial intentions, the correlation is poor as similarly found in Altinay et al (2012), Espíritu-Olmos and Sastre-Castillo (2015), Obschonka, Silbereisen, and Schmitt-Rodermund (2010), and Ozaralli and Rivenburgh (2016). Instead of personality factors, entrepreneurial intentions are more strongly shaped by the role of entrepreneurial education. Entrepreneurial education provides knowledge to conduct business, influences attitude toward entrepreneurial activity, as well as shapes individual orientation and self-confidence in entrepreneurship (Ferreira, Raposo, Rodrigues, Dinis, \& do Paco, 2012; Francisco Liñán, Rodríguez-Cohard, \& Rueda-Cantuche, 2011; Mueller, 2011).

Compared to the original version of SK-Wira (Husna et al., 2018), this revised scale has several advantages. The scale consists of fewer items, so it is easier to use and more efficient for future studies. Regarding the dimensionality of the scale, with clearer internal structure, it will enable additional analyses. The second alternative measurement also eases researchers to investigate entrepreneurial character at a particular domain.

\section{CONCLUSION}

This research involves evaluating the items of Entrepreneurial Characters Scale (SKWira), modifying the scale by adding and eliminating poor items, and re-specifying the model to find the best construction. This study gains several findings. First, SK-Wira can be used as a multidimensional and unidimensional scale. As a multidimensional scale, SK-Wira measures entrepreneurial characteristics in general. As a unidimensional scale, each subscale can serve as an independent scale and can be used to measure specific domains of entrepreneurial characters. In measuring the specific domain, we recommend using the five-item version of the innovativeness scale and the six-item version of the risk-taking scale because they show better model fit. Second, SK-Wira is a reliable and valid measuring tool to measure the general and specific character of entrepreneurship. Third, SK-Wira can be used for entrepreneurship research. The entrepreneurial characters that are measured by this scale indicate associations with related entrepreneurial constructs, such as entrepreneurial intention and and self-efficacy. For further research, researchers suggest the use of the multitrait- 
multimethod approach to obtain SK-Wira associative evidence with other variables.

\section{ACKNOWLEDGEMENT}

This research was funded by Universitas Muhammadiyah Magelang, 2019.

\section{REFERENSI}

Altinay, L., Madanoglu, M., Daniele, R., \& Lashley, C. (2012). The influence of family tradition and psychological traits on entrepreneurial intention. International Journal of Hospitality Management, 31(2), 489-499. https://doi.org/10.1016/j.ijhm.2011.07.00 7

Antoncic, B., Bratkovic Kregar, T., Singh, G., \& Denoble, A. F. (2015). The Big Five Personality-Entrepreneurship Relationship: Evidence from Slovenia. Journal of Small Business Management, 53(3), 819-841. https://doi.org/10.1111/jsbm.12089

Antonites, A. J., \& Wordsworth, R. (2009). Risk tolerance: A perspective on entrepreneurship education. Southern African Business Review, 13(3), 69-85.

Bandura, A. (2018). Toward a Psychology of Human Agency: Pathways and Reflections. Perspectives on Psychological Science, 13(2), 130-136. https://doi.org/10.1177/17456916176992 80

Bird, B. (2019). Toward a theory of entrepreneurial competency. In J. Katz \& A. Corbet (Eds.), Seminal Ideas for the Next Twenty-Five Years of Advances (Advances in Entrepreneurship, Firm Emergence and Growth) (Vol. 21, pp. 115-131). Emerald Publishing Limited. https://doi.org/10.1108/S1074-

754020190000021011

Brändle, L., Berger, E. S. C., Golla, S., \& Kuckertz, A. (2018). I am what I am -
How nascent entrepreneurs' social identity affects their entrepreneurial selfefficacy. Journal of Business Venturing Insights, 9(August 2017), 17-23. https://doi.org/10.1016/j.jbvi.2017.12.001

Brandstätter, H. (2011). Personality aspects of entrepreneurship: A look at five metaanalyses. Personality and Individual Differences, 51(3), 222-230. https://doi.org/10.1016/j.paid.2010.07.00 7

Carraher, S. M., Buchanan, J. K., \& Puia, G. (2010). Entrepreneurial Need for Achievement in China, Latvia, and the USA. Baltic Journal of Management, 5(3), 378-396. https://doi.org/10.1108/17465261011079 767

Carsrud, A., \& Brännback, M. (2011). Entrepreneurial Motivations: What Do We Still Need to Know? Journal of Small Business Management, 49(1), 9-26. https://doi.org/10.1111/j.1540627X.2010.00312.X

Carsrud, A., Brännback, M., Elfving, J., \& Brandt, K. (2017). Motivations: The Entrepreneurial Mind and Behavior. In M. Brännback \& A. L. Carsrud (Eds.), Revisiting the Entrepreneurial Mind (pp. 185-209). Springer International Publishing. https://doi.org/10.1007/9783-319-45544-0_13

Collins, C. J., Hanges, P. J., \& Locke, E. A. (2004). The Relationship of Achievement Motivation to Entrepreneurial Behavior: A Meta-Analysis. Human Performance, 17(1), 95-117.

Cronbach, L. J., \& Meehl, P. E. (1955). Construct validity in psychological tests. Psychological Bulletin, 52, 281-302.

Drost, E. A. (2011). Validity and Reliability in Social Science Research. Education Research and Perspectives, 38(1), 105123. 
Espíritu-Olmos, R., \& Sastre-Castillo, M. A. (2015). Personality traits versus work values: Comparing psychological theories on entrepreneurial intention. Journal of Business Research, 68(7), 1595-1598. https://doi.org/10.1016/j.jbusres.2015.02. 001

Ferreira, J. J., Raposo, M. L., Rodrigues, R. G., Dinis, A., \& do Paco, A. (2012). A model of entrepreneurial intention: An application of the psychological and behavioral approaches. Journal of Small Business and Enterprise Development, 19(3), 424-440.

Fini, R., Grimaldi, R., Marzocchi, G. L., \& Sobrero, M. (2009). The Foundation of Entrepreneurial Intention. In Summer Conference (pp. 17-19). Retrieved from http://ssrn.com/abstract=1313225 2

Frese, M., \& Gielnik, M. M. (2017). The psychology of entrepreneurship. Annual Review of Organizational Psychology and Organizational Behavior, 1, 413438. https://doi.org/10.1146/annurevorgpsych-031413-091326

Furr, R. M. (2011). Scale construction and psychometrics for social and personality psychology. London: SAGE Publications.

Gerhardt, M. W., \& Kickul, J. R. (2007). The Role of Cognitive Style and Risk Preference on Entrepreneurial SelfEfficacy and Entrepreneurial Intentions. Journal of Leadership and Organizational Studies, 13(4), 86-104. https://doi.org/10.1177/10717919070130 041001

Ghasemi, F., Rastegar, A., Jahromi, R. G., \& Marvdashti, R. R. (2011). The relationship between creativity and achievement motivation with high school students' entrepreneurship. Procedia Social and Behavioral Sciences, 30, 1291-1296.

https://doi.org/10.1016/j.sbspro.2011.10.
250

Gudmundsson, E. (2009). Guidelines for translating and adapting psychological instruments. Nordic Psychology, 61(2), 29-45. https://doi.org/10.1027/19012276.61.2.29

Hisrich, R., Langan-Fox, J., \& Grant, S. (2007). Entrepreneurship Research and Practice: A Call to Action for Psychology. American Psychologist, 62(6), 575-589. https://doi.org/10.1037/0003066X.62.6.575

Hooper, D., Coughlan, J., \& Mullen, M. R. (2008). Structural Equation Modelling: Guidelines for determining model fit. Electronic Journal of Business Research Methods, 6(1), 53-60.

Husna, A. N., \& Akmal, N. (2020). Indonesian Adaptation of Entrepreneurial Self-Efficacy Scale. In Advances in Social Science, Education and Humanities Research (Vol. 436, pp. 272277). Atlantis Press. https://doi.org/10.2991/assehr.k.200529.0 56

Husna, A. N., Zahra, A. A., \& Haq, A. L. A. (2018). Skala Karakter Wirausaha (SKWira): Konstruksti dan validasi awal. Jurnal Psikologi, 17(2), 143-160. https://doi.org/https://doi.org/10.14710/jp .17.2.143-160

John, O. P., \& Benet-Martínez, V. (2000). Measurement: Reliability, construct validation, and scale construction. In $\mathrm{H}$. T. Reis \& C. M. Judd (Eds.), Handbook of research methods in social and personality psychology (pp. 339-369). New York: Cambridge University Press.

Krueger, Jr., N. F., \& Brazeal, D. V. (1994). Entrepreneurial Potential and Potential Entrepreneurs. Entrepreneurship Theory and Practice, 18(3), 91-104. 
https://doi.org/10.14211/regepe.v7i2.107 1

Kusmintarti, A., Thoyib, A., Maskie, G., \& Ashar, K. (2016). Entrepreneurial characteristics as a mediation of entrepreneurial education: Influence on entrepreneurial intention. Journal of Entrepreneurship Education, 19(1), 2437.

Lang, J. W. B., \& Fries, S. (2006). A revised 10-item version of the achievement motives scale: Psychometric properties in German-speaking samples. European Journal of Psychological Assessment, 22(3), 216-224. https://doi.org/10.1027/10155759.22.3.216

Laviolette, E. M., Lefebvre, M. R., \& Brunel, O. (2012). The impact of story bound entrepreneurial role models on selfefficacy and entrepreneurial intention. International Journal of Entrepreneurial Behaviour \& Research, 8(6), 720-742. https://doi.org/10.1108/13552551211268 148

Liñán, F., \& Chen, Y.-W. (2009). Development and cross-cultural application of a specific instrument to measure entrepreneurial intentions. Entrepreneurship: Theory and Practice, 33(3), 593-617.

Liñán, Francisco. (2005). Development and Validation of an Entrepreneurial Intention Questionnaire (EIQ). In 15th Internationalizing Entrepreneurship Education and Training Conference (pp. 1-14).

Liñán, Francisco, Rodríguez-Cohard, J. C., \& Rueda-Cantuche, J. M. (2011). Factors affecting entrepreneurial intention levels: A role for education. International Entrepreneurship and Management Journal, $\quad 7(2), \quad$ 195-218. https://doi.org/10.1007/s11365-0100154-z
Lumpkin, G. T., Cogliser, C. C., \& Schneider, D. R. (2009). Understanding and Measuring Autonomy: An Entrepreneurial Orientation Perspective. Entrepreneurship Theory and Practice, 14(806), 47-70. https://doi.org/10.1111/j.15406520.2008.00280.x

McCrae, R. R., \& Costa, P. T. (2013). Introduction to the empirical and theoretical status of the five-factor model of personality traits. In T. A. Widiger \& P. T. Costa (Eds.), Personality disorders and the five-factor model of personality (pp. 15-27). https://doi.org/10.1037/13939-002

McGee, J. E., Peterson, M., Mueller, S. L., \& Sequeira, J. M. (2009). Entrepreneurial self-efficacy: Refining the measure. Entrepreneurship Theory and Practice, 33(4), 965-988. https://doi.org/10.1111/j.15406520.2009.00304.x

Mueller, S. (2011). Increasing entrepreneurial intention: Effective entrepreneurship course characteristics. International Journal of Entrepreneurship and Small Business, 13(1), 55-74. https://doi.org/10.1504/IJESB.2011.0404 16

Newman, A., Obschonka, M., \& Schwarz, S. (2018). Entrepreneurial self-efficacy: A systematic review of the literature on its antecedents and outcomes, and an agenda for future research. Journal of Vocational Behavior, 110, 403-419. https://doi.org/10.1016/j.jvb.2018.05.012

Obschonka, M., Silbereisen, R. K., \& Schmitt-Rodermund, E. (2010). Entrepreneurial intention as developmental outcome. Journal of Vocational Behavior, 77(1), 63-72. https://doi.org/10.1016/j.jvb.2010.02.008

Obschonka, M., \& Stuetzer, M. (2017). 
Integrating psychological approaches to entrepreneurship: The Entrepreneurial Personality System (EPS). Small Business Economics, 49(1), 203-231. https://doi.org/10.1007/s11187-0169821-y

Ozaralli, N., \& Rivenburgh, N. K. (2016). Entrepreneurial intention: antecedents to entrepreneurial behavior in the U.S.A. and Turkey. Journal of Global Entrepreneurship Research, 6(1). https://doi.org/10.1186/s40497-0160047-x

Ramdhani, N. (2012). Adaptasi bahasa dan budaya inventory Big Five. Jurnal Psikologi, 39(2), 189-207. Retrieved from

https://journal.ugm.ac.id/jpsi/article/view File/6986/5438

Rauch, A., \& Frese, M. (2000). Psychological approaches to entrepreneurial success: A general model and an overview of findings. In C. L. Cooper \& I. T. Robertson (Eds.), International review of industrial and organizational psychology (pp. 101142). Chichester: Wiley. https://doi.org/10.1111/j.15406520.2007.00230.x

Rauch, A., \& Frese, M. (2014). Born to Be an Entrepreneur? Revisiting the Personality Approach to Entrepreneurship. In J. R. Baum, M. Frese, \& R. A. Baron (Eds.), The Psychology of Entrepreneurship (pp. 7398). New York: Psychology Press.

Salamzadeh, A., Farjadian, A. A., Amirabadi, M., \& Modarresi, M. (2014). Entrepreneurial characteristics: Insights from undergraduate students in Iran. International Journal of Entrepreneurship and Small Business, 21(2), 165-182. https://doi.org/10.1504/IJESB.2014.0594 71
Shane, S., Locke, E. A., \& Collins, C. J. (2012). Entrepreneurial Motivation. Human Resource Management Review, 13(2), 257-279. Retrieved from http://digitalcommons.ilr.cornell.edu/artic les/830\%0ARequired

Shane, S., Nicolaou, N., Cherkas, L., \& Spector, T. D. (2010). Genetics, the Big Five, and the Tendency to Be SelfEmployed. Journal of Applied Psychology, 95(6), 1154-1162. https://doi.org/10.1037/a0020294

Sousa, V. D., \& Rojjanasrirat, W. (2011). Translation, adaptation and validation of instruments or scales for use in crosscultural health care research: A clear and user-friendly guideline. Journal of Evaluation in Clinical Practice, 17(2), 268-274. https://doi.org/10.1111/j.13652753.2010.01434.x

Stajkovic, A. D., \& Luthans, F. (1998). SelfEfficacy and Work-Related Performance: A Meta-Analysis. Psychological Bulletin, 124(2), 240-261. https://doi.org/10.1037/0033-

2909.124.2.240

Stewart, W. H., \& Roth, P. L. (2001). Risk propensity differences between entrepreneurs and managers: A metaanalytic review. Journal of Applied Psychology, 86(1), 145-153. https://doi.org/10.1037/00219010.86.1.145

Stewart, W. H., \& Roth, P. L. (2007). A Meta-Analysis of Achievement Motivation Differences between Entrepreneurs and Managers. Journal of Small Business Management, 45(4), 401421.

Thompson, E. R. (2009). Individual Entrepreneurial Intent: Construct clarification and development of an internationally reliable matric. Entrepreneurship Theory and Practice, 33(3),

669-695. 
https://doi.org/10.1111/j.1540-

6520.2009.00321.x

Utsch, A., \& Rauch, A. (2002). Innovativeness and initiative as mediators between achievement orientation and venture performance. European Journal of Work and Organizational Psychology, 9(1), 45-62. https://doi.org/10.1080/13594320039805 8

Wu, S., Matthews, S., \& Dagher, G. K. (2007). Need for achievement, business goals, and entrepreneurial persistence. Management Research News, 30(12), 928-941.

https://doi.org/10.1108/01409170710833 358

Zhao, H., Seibert, S. E., \& Hills, G. E. (2005). The mediating role of selfefficacy in the development of entrepreneurial intentions. Journal of Applied Psychology, 90(6), 1265-1272. https://doi.org/10.1037/00219010.90.6.1265 